\title{
Enhancement of the Cytotoxic Effect of Mitomycin C by $\beta$-Adrenergic Stimulants in Rat Ascites Hepatoma AH130 Cells
}

\author{
Kenichi MIYAMOTO, Takayuki MATSUNAGA, Yoshihiro WAKI \\ and Ryozo KOSHIURA \\ Department of Pharmacology, Hokuriku University School of Pharmacy. \\ Ho-3 Kanagawa-machi, Kanazawa 920-11, Japan
}

Accepted November 30, 1985

\begin{abstract}
Among several sympathomimetic drugs, isoproterenol, epinephrine and norepinephrine significantly potentiated the cytotoxic effect and the uptake of MMC into rat ascites hepatoma AH130 cells in in vitro experiments, but salbutamol, tulobuterol and phenylephrine did not. The enhancement of MMC uptake into $\mathrm{AH} 130$ cells by isoproterenol and norepinephrine was diminished by propranolol but not by phentolamine. These results indicate that the cytotoxic effect and the uptake of $\mathrm{MMC}$ is potentiated by the stimulation of $\beta$-adrenoceptors, but not by stimulation of $\beta_{2}$ - and $\alpha$-receptors.
\end{abstract}

We have recently shown that isoproterenol, a $\beta$-adrenergic stimulant, enhanced the cytotoxic effect of mitomycin C (MMC) on HeLa cells and some rat ascites hepatoma $(\mathrm{AH})$ cells $(1,2)$. Furthermore, it has been suggested that cyclic adenosine $3^{\prime}: 5^{\prime}$ monophosphate (cyclic AMP) in AH44 and AH130 cells elevated by this drug increased the uptake of MMC (3). The present paper deals with the effects of several sympathomimetic drugs on the cytotoxicity and the uptake of MMC in AH130 cells.

Agents obtained from commercial sources were mitomycin C (MMC, Sankyo Co.); 1isoproterenol hydrochloride, I-epinephrine bitartrate, I-norepinephrine hydrochloride, and dl-propranolol hydrochloride (Sigma Chemicals Co.); and dl-phentolamine mesylate (Ciba-Geigy Japan Ltd.). dl-Salbutamol hemisulfate and $\mathrm{dl}$-tulobuterol hydrochloride were kindly provided by Hokuriku Seiyaku Co., Katsuyama.

Rat ascites hepatoma AH130 cells were maintained serially by the intraperitoneal passage at weekly intervals in female Donryu rats (weight 100-150 g. Shizuoka Laboratory Animal Center). The cells were withdrawn from the abdominal cavity of a rat at 7 to 9 days after the their implantation, washed with Hanks' solution to remove red blood cells and suspended in Eagle's minimum essential medium (Eagle's MEM) to a concentration of about $4 \times 10^{5}$ cells $/ \mathrm{ml}$. The cells were preincubated with an adrenergic agonist for $15 \mathrm{~min}$ and then exposed to MMC for $30 \mathrm{~min}$ at $37^{\circ} \mathrm{C}$. The treated cells were washed with Hanks' solution, suspended in Eagle's MEMsupplemented $10 \%$ fetal calf serum and cultured in $35-\mathrm{mm}$ plastic petri dishes (Falcon 3001) in a $5 \% \mathrm{CO}_{2}$ incubator for 2 days at $37^{\circ} \mathrm{C}$. The viable cells were assayed by the staining method with $0.2 \%$ Trypan Blue.

Cells were pretreated with an adrenergic agonist in the presence or the absence of an antagonist in phosphate-buffered saline for $15 \mathrm{~min}$. After cells were further incubated with $\mathrm{MMC}(10 \mu \mathrm{g} / \mathrm{ml})$ for $30 \mathrm{~min}$, the contents of MMC in the supernatant of the incubation mixture were measured by analytical high performance liquid chromatography [HPLC, Yanaco L-5000 liquid chromatograph equipped with a Yanaco $M$ 315 spectromonitor; Yanapak ODS-A stainless column, $25 \mathrm{~cm} \times 4.6 \mathrm{~mm}$ i.d.; mobile phase: $0.01 \mathrm{M}$ phosphate buffer $(\mathrm{pH}$ 6.0): methanol (70:30, VN); flow rate: 1.0 $\mathrm{ml} / \mathrm{min}$; wave length: $363 \mathrm{~nm}$ ] according to the method of Hartigh and Oort (4); and the amounts of MMC taken up into the cells 
were determined from the decreased amount of $\mathrm{MMC}$ in the supernatant as described elsewhere (3).

Figure 1 shows the effects of sympathomimetic drugs on the cytotoxic effect and the uptake of MMC. Isoproterenol, epinephrine and norepinephrine significantly potentiated the cytotoxicity of MMC, and
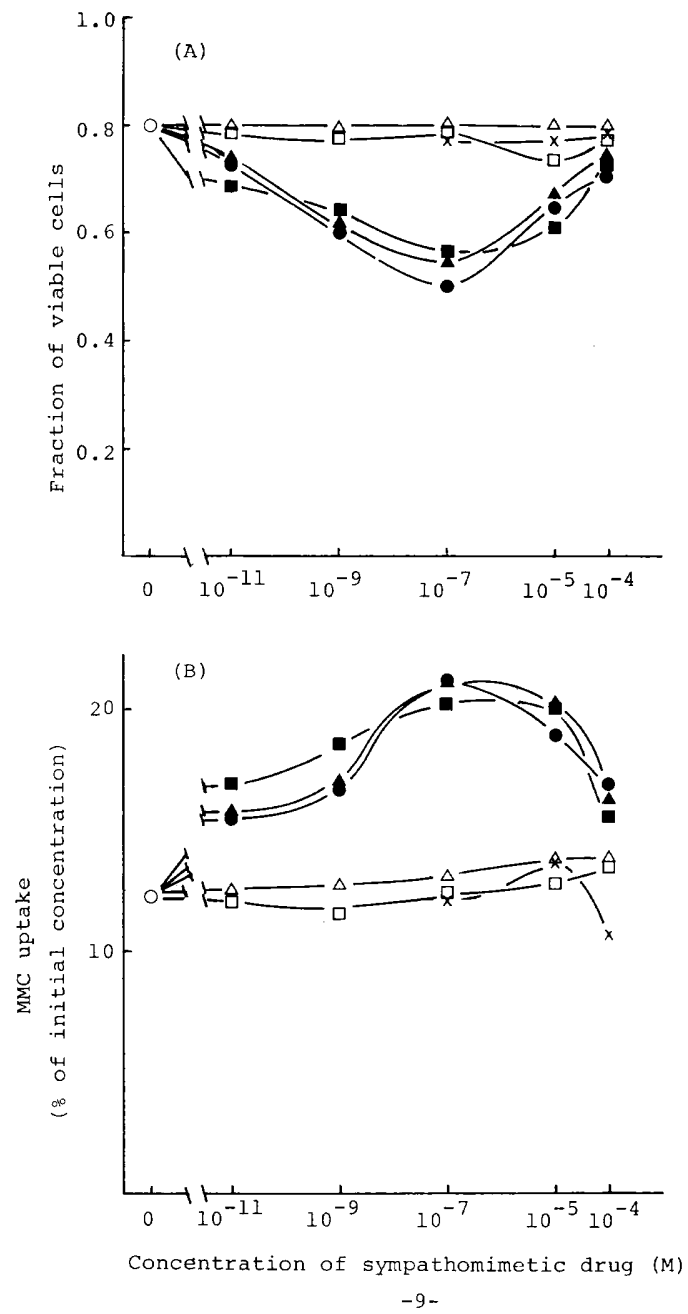

Fig. 1. Effect of sympathomimetic drugs on the cytotoxicity and the uptake of MMC to AH130 cells. Cells $\left[4 \times 10^{5}\right.$ cells $/ \mathrm{ml}$ in $(A)$ and $10^{7}$ cells $/ \mathrm{ml}$ in (B)] were incubated with various concentrations of each sympathomimetic drug for $15 \mathrm{~min}$ and then exposed to MMC $[0.03 \mu \mathrm{g} / \mathrm{ml}$ in (A) and $10 \mu \mathrm{g} / \mathrm{ml}$ in (B)] for $30 \mathrm{~min}$. : isoproterenol, $\mathbf{A}$ : epinephrine, $\square$ : norepinephrine, $\square$ : salbutamol, $\times$ : tulobuterol, $\triangle$ : phenylephrine.
$1 \times 10^{-7} \mathrm{M}$ of each drug was the most effective dose. However, salbutamol and tulobuterol, which were reported to act as $\beta_{2}$-agonists (5), and phenylephrine, an $\alpha$ agonist, hardly influenced the cytotoxic effect of MMC (Fig. 1A). The dose-response curve of MMC was shifted to the left by the pretreatment with isoproterenol, epinephrine or norepinephrine (data not shown). The effects of these drugs on the uptake of MMC are shown in Fig. 1B. The cells treated with isoproterenol, epinephrine or norepinephrine took up MMC about twice as much as nontreated cells. However, salbutamol, tulobuterol and phenylephrine did not change the uptake of MMC. Thus, it was confirmed that the enhancement of the cytotoxic effect of $M M C$ was related to the increase of the uptake of MMC by $\beta$-adrenergic agonists, except for $\beta_{2}$-agonists. It is known that rat liver cells contain only $\beta_{2}$-receptor among the subtypes of $\beta$-adrenoceptor (6). On the other hand, we have suggested that rat ascites hepatoma cells may possess some receptors having similar properties to the mammalian $\beta_{1}$-receptor because their adenylate cyclase hardly responded to $\beta_{2}$ agonists, and the enzyme activity stimulated by isoproterenol was more selectively inhibited by $\beta_{1}$-antagonists in hepatoma cells than in normal rat liver cells (7). This study also indicates that $\beta_{2}$-agonists are not potent for enhancing the cytotoxic effect of MMC and not potent for increasing the uptake of MMC.

Our recent papers $(1,2)$ have indicated that isoproterenol elevated intracellular cyclic AMP via $\beta$-adrenoceptors, and MMC prolonged the term of the high cyclic AMP level, suggesting that the intracellular cyclic AMP elevated by the combined action of isoproterenol and MMC enhanced the uptake and the antitumor effect of MMC. The enhancement of MMC uptake by isoproterenol or norepinephrine was diminished by the $\beta$-antagonist propranolol, but not diminished by the $\alpha$-antagonist phentolamine (Fig. 2). Phenylephrine which acts through $\alpha$-adrenoceptors was not effective on the cytotoxicity and the uptake of MMC (Fig. 1). Consequently, this study indicates that the enhanced cytotoxicity of MMC is obtained 


Control
Phentolamine
Propranolol
Isoproterenol
Isoproterenol
+Phentolamine
Isoproterenol
+Propranolol
Norepinephrine
Norepinephrine
+Phentolamine
Norepinephrine
+Propranolol

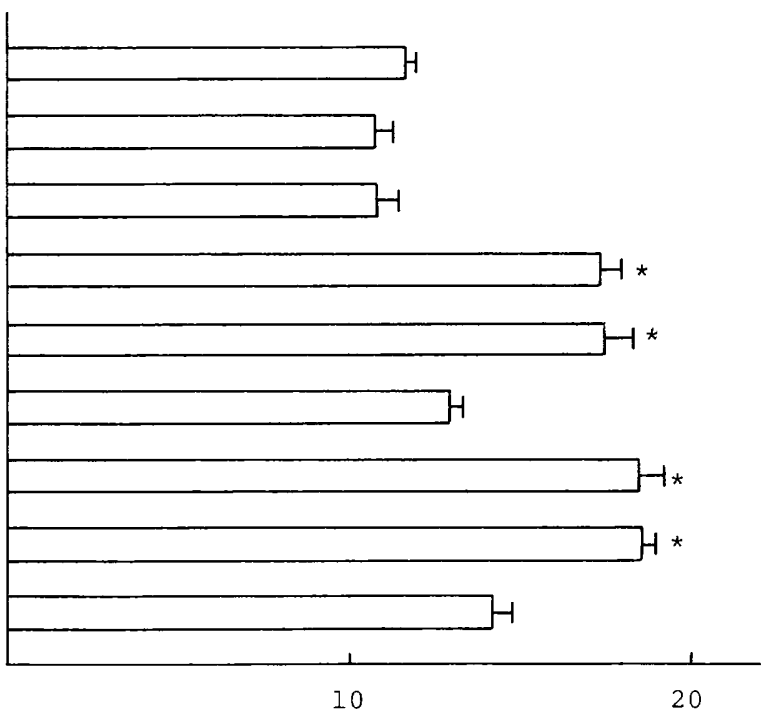

MMC uptake

( $\frac{\circ}{\partial}$ of initial concentration)

Fig. 2. Influence of propranolol and phentolamine on the effect of isoproterenol and norepinephrine on the uptake of $\mathrm{MMC}$ in $\mathrm{AH} 130$ cells. An adrenergic antagonist $\left(10^{-5} \mathrm{M}\right)$ was added to the cells $\left(10^{7}\right.$ cells $/ \mathrm{ml})$ and then they were incubated with an agonist $\left(10^{-7} \mathrm{M}\right)$ for $15 \mathrm{~min}$. The pretreated cells were exposed to MMC $(10 \mu \mathrm{g} / \mathrm{ml})$ for $30 \mathrm{~min}$. Values are the mean \pm S.E. of 3 experiments. ${ }^{*} P<0.05$ : Significantly different from the control.

through an increase in the uptake of the antitumor agent by the stimulation of $\beta$ adrenoceptors, but not by the stimulation of $\beta_{2}$-receptors in rat ascites hepatoma cells.

\section{References}

1 Miyamoto, K., Sanae, F., Iwasaki, M. and Koshiura, R.: Effect of $\beta$-adrenergic stimulants on cytotoxicity of mitomycin $\mathrm{C}$ in HeLa cells. Japan. J. Pharmacol. 32, 1019-1026 (1982)

2 Matsunaga, T., Iwasaki, M., Miyamoto, K. and Koshiura, R.: Relationship between enhancement of cytotoxic effect of mitomycin $\mathrm{C}$ and increase of intracellular cyclic adenosine $3^{\prime}: 5^{\prime}$-monophosphate by isoproterenol in rat ascites hepatoma cells. J. Pharmacobiodyn. 6, 25-32 (1983)

3 Miyamoto, K., Matsunaga, T., Waki, Y. and Koshiura, R.: Enhancement of mitomycin C uptake by isoproterenol in rat ascites hepatoma.
J. Pharmacobiodyn. (in press)

4 Hartigh, J.D. and Oort, W.J.: High-performance liquid chromatographic determination of the antitumor agent mitomycin $C$ in human blood plasma. Anal. Chim. Acta 127, 47-53 (1981)

5 Minneman, K.P., Hegstrand, L.R. and Molinoff, P.B.: The pharmacological specificity of beta-1 and beta- 2 adrenergic receptors in rat heart and lung in vitro. Mol. Pharmacol. 16, 21-33 (1979)

6 Minneman, K.P., Hedberg, A. and Molinoff, P.B.: Comparison of beta adrenergic receptor subtypes in mammalian tissues. J. Pharmacol. Exp. Ther. 211, 502-508 (1979)

7 Miyamoto, K., Matsunaga, T., Takemoto, N., Sanae, F. and Koshiura, R.: Studies on responsiveness of hepatoma cells to catecholamines: II Comparison of $\beta$-adrenergic responsiveness of rat ascites hepatoma cells with cultured normal rat liver cells. Japan. J. Pharmacol. 38, 101-108 (1985) 